\title{
Cryptic species in Pagamea coriacea sensu lato (Rubiaceae): evidence from morphology, ecology and reproductive behavior in a sympatric context
}

\author{
Samantha de Miranda ESTEVES ${ }^{1}$, Alberto VICENTINI ${ }^{1}$
}

\begin{abstract}
In this study we explore morphological and ecological variation in sympatric populations of Pagamea coriacea s.l. - a species complex from white-sand vegetation in the Amazon. A total of 147 trees were sampled and monitored at three nearby sites in Central Amazon, Brazil. Multivariate analyses of morphology indicated two distinct groups (A and B), which also differed in bark type, each containing subgroups associated with sexual dimorphism. However, a single hermaphroditic individual was observed within group B. As expected, all pistillate plants produced fruits, but $23 \%$ of the staminate plants of group B, and $5 \%$ of group A also produced fruits. This variation suggests that the sexual systems of both groups are between dioecy and gynodioecy. There was an overlap in flowering phases between the two groups, but the pattern of floral maturation differed. Ecologically, plants of group B were found in more shaded habitats and over sandstone bedrocks, while group A was prevalent in deeper sandy soils as canopy plants. The significances of morphological and environmental differences were tested by a multivariate analysis of variance, and a canonical discriminant analysis assessed the importance of variables. The coexistence in sympatry of two discrete morphological groups in the P. coriacea s.l., with different habitat preferences and reproductive behaviors, indicates they represent distinct species.
\end{abstract}

KEYWORDS: Population ecology, species delimitation, reproductive system variation, white-sand forests, Amazonia.

\section{Espécies crípticas em Pagamea coriacea sensu lato (Rubiaceae): evidências morfológicas, ecológicas e de comportamento reprodutivo em um contexto simpátrico}

\section{RESUMO}

O objetivo deste estudo foi testar se o complexo de espécies Pagamea coriacea inclui múltiplas espécies, usando evidências morfológicas, ecológicas e de comportamento reprodutivo. Um total de 147 árvores foram amostradas e monitoradas em três locais próximos na Amazônia Central, Brasil. Análises multivariadas de dados morfológicos indicaram dois grupos discretos (A e B), que coincidem com diferenças no tipo de casca, cada um por sua vez com subgrupos que representam dimorfismo sexual. Contudo, um indivíduo distintamente hermafrodita foi encontrado no grupo B. Todas as plantas pistiladas produziram frutos, mas também foram observados frutos para 23\% das plantas estaminadas do grupo B, e para 5\% das estaminadas do grupo A. Essa variação sugere que ambos grupos possuem um sistema sexual entre dioicia e ginodioicia. Houve sobreposição das fases de floração e frutificação entre os dois grupos, mas o padrão de maturação de flores foi diferente. Quanto ao hábitat, o grupo B predominou em situaçóes de sombra e em solos arenosos rasos sobre lajes de pedra, enquanto o grupo A ocorreu em solos arenosos mais profundos e no dossel da vegetação. A coexistência de dois grupos morfológicos discretos no complexo P. coriacea s.l., com diferenças ecológicas e de comportamento reprodutivo, indica que correspondem a duas espécies distintas. PALAVRAS-CHAVE: Ecologia de populaçóes, delimitação de espécies, variação em sistema reprodutivo, campinarana, Amazônia.

\footnotetext{
1 Instituto Nacional de Pesquisas da Amazônia, Programa de Pós-Graduação em Ecologia, Av. Andre Araújo 2936, CEP: 69.060-001, Manaus-AM, Brazil.
} Tel: +55 (92) 3643-3105. Emails: vicentini.beto@gmail.com; xuleta@gmail.com 


\section{INTRODUCTION}

Although a basic term in biology, the species concept has generated a long debate in the scientific literature, with around 22 published definitions (Mayr 1992; Mayden 1997). However, most species concepts agree that species represent segments of population level evolutionary lineages, and their definitions are rather criteria identifying particular stages of the process of species formation (General Lineage Concept; de Queiroz 1998 and 2007). Speciation can occur in several ways and species may be at distinct stages of divergence (Wien 2007), which may hamper the recognition of limits among closely related species, or among incipient species, i.e. those in the early stages of divergence. Therefore, for species delimitation multiple criteria and types of evidence are usually required, permitting a better characterization of the species and of the historical process of species formation (Sites and Marshall 2004; Reeves and Richards 2011).

In practice, plant species are usually recognized on the basis of morphological data (McDade 1995), and the operational criteria of the concept adopted are rarely mentioned (e.g. Sites and Marshall 2004; Valcárcel and Vargas 2010). Classification based on morphology is practical and makes biological sense, since genetic differences among reproductively isolated populations usually reflect phenotypic differences (Wien 2007). However, morphological differences may only represent phenotypic plasticity, where the plant's form changes in response to environmental variation (Schlichting 1986), or phenotypic differences associated with geographical variation (Mayr 1992; Mitchell-Olds and Schmitt 2006). Therefore, species recognition using purely morphological criteria may be misleading, especially in highly diverse Amazonia, where plant knowledge and sampling is scant (Hopkins 2007).

Ultimately, reproductive isolation should be the major criterion for species delimitation, because speciation entails the establishment of reproductive barriers between lineages. Problems arise because different species may hybridize, a common phenomenon in plants (Grant 1981), and because reproductive isolation is usually inferred indirectly, making it difficult to assess whether allopatric populations are reproductively isolated or not (Mayr 1992). On the other hand, the identification of differences in a local, sympatric, context -- the adimensional species of Mayr (1992), may be indirect evidence of species reproductive isolation. While genetic differences among sympatric populations may be strong evidence for the lack of gene flow, morphological differences can indicate reproductive isolation if phenotypic plasticity is ruled out. Hence, although reproductive isolation is a fundamental guiding criterion for species delimitation (Coyne and Orr 2004), different types of evidence may be required to infer it.
When dealing with species in the early stages of divergence the use of multiple types of evidence and analytical approaches is particularly important (Morando et al. 2003; Sites and Marshall 2004; Shaffer and Thomson 2007). Although methodologies using molecular data (Templeton 2001; Hebert et al. 2003; Pons et al. 2006; Knowles and Carstens 2007), have accelerated and facilitated species recognition, they may not be sufficient for the delimitation of recently diverged species (Will et al. 2005; Brower 2006; Hickerson et al. 2006; Gonzales et al. 2009), stressing the importance of studies at the population level (Knowles and Carstens 2007; Shaffer and Thomson 2007). Furthermore, information on natural history, reproductive biology, and/or ecological characteristics in situ for species delimitation, and for the understanding of speciation, is rarely sought (Marshall et al. 2006; Leaché et al. 2009; Reeves and Richards 2011).

Pagamea coriacea Spruce ex Benth. sensu lato (Rubiaceae) is a species complex of trees that occurs only in Amazonian white-sand forests ("Campinaranas"), an insular vegetation type (Prance 1996) associated with sandy and oligotrophic soils (Veloso et al. 1991). The complex exhibits ample morphological variation and Steyermark (1965) recognized three different varieties within it: Pagamea coriacea var. acuta Steyerm., var. pubescens Steyerm., and var. coriacea. He distinguished variety acuta as having the leaf apex acute, versus a rounded leaf apex in the other two; variety pubescens differed from var. coriacea in presenting tufts of hairs (acarodomatia) at the secondary vein axes, and a denser and larger indument on the corolla and calyx lobes. However, these varieties were each described based on one to two specimens only, no discussions were provided as to why they should be different varieties, and these infra-specific names have been largely neglected or treated as synonyms (Zappi 2012).

Vicentini (2007) provided the first evidence that the complex is monophyletic, according to both nuclear and chloroplast markers, and dated its origin to approximately 6 million years ago. He also recognized a new species within this clade: Pagamea "igapoana" representing a single population in the Upper Rio Negro region that occurs in Igapó flooded forests, and is also morphologically very distinct from sympatric individuals of $P$. coriacea sensu lato, which are restricted to Campinarana non-flooded forests and shrublands. The phylogenetic relationship between these species remained unclear due to the lack of sampling and resolution, with $P$. coriacea s. $l$. being paraphyletic and having $P$. "igapoana" nested within it (Vicentini 2007). P. coriacea s.l. may itself include more than one species, based on the coexistence of two distinct morphological groups in the Upper Rio Negro region, and the observation of polymorphic populations in the municipality of Presidente Figueiredo, Amazonas, Brazil (Vicentini 2007). Furthermore, floral morphological variation indicated the 
presence of three reproductive systems within $P$. coriacea s.l. - dioecy, heterostyly and homostyly, an unusual variation for a single species, being a conserved trait in all other species of Pagamea (Vicentini 2007). Therefore, the number of species in the $P$. coriacea clade and their delimitation remain unclear, and so their geographical distribution and species status.

Here, the morphological, phenological, and ecological variation in the $P$. coriacea complex was analyzed in detail for three localities within the municipality of Presidente Figueiredo, in order to clarify the intra or interspecific nature of the variation present at this locality.

\section{MATERIALS AND METHODS}

There are several white-sand forest areas in the municipality of Presidente Figueiredo (02 03'03.7” S, 60 07' 07.4” W). Sandstone outcrops are abundant in the region, as well as shallow soils overlying sandstone bedrocks, increasing the complexity and heterogeneity of the white-sand vegetation. In many places, soils are hydromorphic, becoming waterlogged during rainy periods.

We selected three white-sand forest areas for this study: (I) an area located at the margin of the Urubu River $\left(02^{\circ} 03^{\prime}\right.$ 03.7” S, 60 07' 21.9" W), close to the Princesinha do Urubu waterfall, in a private land with little or no human activity; (II) an area located at the margin of the Urubuí River, at the Iracema Falls touristic complex ( $01^{\circ} 98^{\prime} 74.9^{\prime \prime} \mathrm{S}, 60^{\circ} 05^{\prime} 99.3^{\prime \prime}$ W); and (III) an area close to the Igarapé dos Veados $\left(02^{\circ} 03^{\prime}\right.$ $18.11^{\prime \prime}$ S, $60^{\circ} 01^{\prime} 25.7^{\prime \prime}$ W), a tributary of the Urubuí River, at the Cachoeira das Orquídeas Municipal Park. The three areas are surrounded by terra firme forest (Floresta Ombrófila Densa; sensu Veloso et al. 1991) and separated by at least 10 $\mathrm{km}$. Isolated patches of white-sand forest occur along the rivers and may act as stepping-stones for the dispersal of organisms that are restricted to this vegetation type. In each area, three $200 \mathrm{~m}$ trails perpendicular to the river were established and all adult individuals of $P$. coriacea s.l. detected within approximately $10 \mathrm{~m}$ of each side of the trail were sampled and tagged. A total of 308 individuals were marked, 128 in area I, 104 in area II, and 76 in area III. Fertile samples of 147 trees were obtained in 2010, beginning in October, when flowering started, and ending in December, when few flowering individuals remained.

Fifteen morphological variables of leaves, flowers, and inflorescences were measured to describe morphological variation in the complex (Table 1). For flower variables, samples of 66 individuals were randomly selected, and five flowers per individual were dissected, for which calyx length, petal length, stigma length, and anther length were measured with a digital caliper. The filament+anther and style+stigma heights relative to the flower base were measured to describe variation in sexual system. Inflorescence characters were measured for 71 individuals from scanned images of four inflorescences per individual. For each inflorescence, total length, peduncle length, and length of the first lateral axis were measured with the Image J program (Rasband 2004). For inflorescences, a shape descriptor was also calculated ("Shape 1" in Table 1) by dividing the peduncle length by the total length, which thus describes how much of the total length corresponds to the peduncle. For leaves, digital images of four leaves per individual were obtained for a total of 110 individuals. From those images, total leaf length, total leaf width, and length of the petiole of each leaf were measured. To describe the shape of the leaf blade, we extracted Fourier coefficients that describe the leaf blade contour from digital images with the program Shape (Iwata and Ukai 2002); the leaf contour is registered as a chain-code (Freeman 1974), with which normalized elliptical Fourier descriptors are calculated.

To identify morphological groups, we performed a cluster analysis using the minimum variance grouping method ('ward') and a dissimilarity matrix calculated using

Table 1 - Morphological variables measured for morphometric study.

\begin{tabular}{|c|c|c|}
\hline Variable & Unit & Definition \\
\hline \multicolumn{3}{|l|}{ FLOWERS } \\
\hline Stamen height & $\mathrm{mm}$ & $\begin{array}{l}\text { Length from petal base to } \\
\text { anther apex }\end{array}$ \\
\hline Stigma height & $\mathrm{mm}$ & $\begin{array}{l}\text { Length from petal base to } \\
\text { stigma apex }\end{array}$ \\
\hline Calyx length & $\mathrm{mm}$ & Length from calyx base to apex \\
\hline Anther length & $\mathrm{mm}$ & Anthers total length \\
\hline Petal length & $\mathrm{mm}$ & Length from petal base to apex \\
\hline Stigma length & $\mathrm{mm}$ & Length of stigmatic lobes \\
\hline \multicolumn{3}{|l|}{ INFLORESCENCES } \\
\hline Inflorescence length $(\mathrm{IL})^{*}$ & $\mathrm{~mm}$ & $\begin{array}{l}\text { Length from inflorescence base } \\
\text { to apex }\end{array}$ \\
\hline Peduncle length $(\mathrm{PL})^{*}$ & $\mathrm{~mm}$ & $\begin{array}{l}\text { Length from base to } 1 \mathrm{st} \\
\text { branching }\end{array}$ \\
\hline Length of 1st side branch (BL)* & $\mathrm{mm}$ & Length of first lateral axis \\
\hline Shape descriptor I - PL/IL* & ratio & $\begin{array}{l}\text { Inflorescence peduncle length } \\
\text { divided by the inflorescence } \\
\text { total length }\end{array}$ \\
\hline \multicolumn{3}{|l|}{ LEAVES } \\
\hline Leaf length (LL)* & $\mathrm{mm}$ & $\begin{array}{l}\text { Length from petiole base to } \\
\text { apex }\end{array}$ \\
\hline Width $(\mathrm{LW})^{*}$ & $\mathrm{~mm}$ & $\begin{array}{l}\text { Width of leaf blade at widest } \\
\text { point }\end{array}$ \\
\hline Petiole length (PtL)* & $\mathrm{mm}$ & Total length of the petiole \\
\hline Shape descriptor I - LL/LW* & ratio & Leaf width divided by leaf length \\
\hline Shape descriptor II - PtL/LL* & ratio & $\begin{array}{l}\text { Petiole length divided by leaf } \\
\text { length }\end{array}$ \\
\hline
\end{tabular}

$\left.{ }^{\star}{ }^{\star}\right)$ Variables used to compare with Vicentini's (2007) data to predict geographical distribution. 
the Gower coefficient from the average values for the flower, the inflorescence, and the leaf variables for each individual. Leaf shape was analyzed separately by a principal component analysis (PCA) with the Shape program (Iwata and Ukai 2002), using the normalized Fourier descriptors and a variance-covariance matrix following the procedure proposed by Furuta et al. (1995).

Besides morphometric data, trunk bark images were obtained for 38 individuals, because two patterns were initially recognized in the field. The images were then classified independently by three different people, which did not participate in the study and were not familiar with the plants in the field. All of them recognized two groups of barks that were designated "fissured" and "scaly" types. The congruence and ambiguity in bark image classification were mapped over the cluster analysis as an independent evidence of group recognition.

Monthly visits were conducted to the three areas between January 2010 and February 2011, except for March, April and May 2010. The phenological study consisted in qualitative and quantitative observations of eleven phenophases: sterile, inflorescences beginning to develop, inflorescences with incompletely formed buds, completely developed (although immature) buds, mature buds, open flowers, calyces without corolla, fruits beginning to develop, developed (but unripe) fruits, mature fruits, and old inflorescences. To describe the pattern of flower maturation, we used the same inflorescences used to collect morphometric data, for which we quantified the total number of immature and mature buds. Three inflorescences per individual were sampled for 23 samples, and the average proportions of immature buds and mature buds per inflorescence per individual were calculated. Flowers were checked for gynoecium and androecium functionality or sterility, considering that stamina were sterile when they lacked pollen grains, and pistils were sterile when stigma was not expanded nor papillose. The ratio between stamen height $(\mathrm{StH})$ and stigma height $(\mathrm{SmH})$, relative to the flower base, allowed the separation of floral morphologies indicative of heterostyly (brevistylic or longistylic), homostyly, and intermediate situations (Faivre and McDade 2001). These values $(\mathrm{StH}-\mathrm{SmH})$ were plotted on a dispersion plot. Transverse cuts were made in the ovaries to check for the presence of ovules. In the field, 79 individuals with staminate flowers were checked for fruit production. We define, hereafter, as "staminate" the plants that presented flowers with fertile stamina, which were long and positioned above the height of a very reduced pistil with non-papillose and closed stigmatic lobes (Figure $1 \mathrm{~A}, \mathrm{C}, \mathrm{M}, \mathrm{O}$ ); and, as "pistillate" the plants whose flowers presented sterile stamina and a long pistil with open and papillose stigma lobes positioned above the reduced stamina (Figure 1 B, D, N, P).
Six variables describing the environment in the vicinity of each 160 plants were collected (Table 2). The height of each individual and the height of the canopy over the individual were estimated in meters, and a shade index value was calculated as the differences between these estimates. The amount of litter accumulated $(\mathrm{cm})$ above the soil close to the individual was measured with a rod graduated in millimeters, positioned perpendicularly to the ground. Next, the root mat that typically forms on the sandy soils of Campinarana forests was cut to measure its thickness $(\mathrm{cm})$. Soil depth was also recorded until reaching the bedrock, or until $50 \mathrm{~cm}$ (length of the tool used).

To test the significance of morphological and environmental differences between the two groups recognized a posteriori, a multivariate analysis of variance (MANOVA) was performed to identify which variables were more important for group discrimination. Next, a canonical discriminant analysis (CDA) was conducted to assess the relative importance of each variable.

Finally, 116 samples of the P. coriacea s.l. measured by Vicentini (2007) and representing plants from several sites along its geographical distribution were classified according to the groups recognized by the discriminant model built with the data collected in this study. Theses analyses included nine quantitative leaf and inflorescence variables shared among the data of Vicentini and those of this study (Table 1). Data were $\log$-transformed. The probability that the sample belonged to the predicted class was also calculated. All the analyses were implemented through scripts constructed for the R language (R Core Team 2012).

Table 2 - Environmental variables measured for habitat characterization.

\begin{tabular}{lll}
\hline Variable & Type & Unit \\
\hline Plant height & Continuous & $\mathrm{m}$ \\
Canopy height & Continuous & $\mathrm{m}$ \\
Root mat thickness & Continuous & $\mathrm{cm}$ \\
Depth to the bedrock & $\begin{array}{l}\text { Continuous up to } 50 \mathrm{~cm} \\
\text { depth }\end{array}$ & $\mathrm{cm}$ \\
Litter thickness & Continuous & $\mathrm{cm}$ \\
Shade Index & Proportion & $\begin{array}{l}\text { Canopy height - plant } \\
\text { height }\end{array}$ \\
\hline
\end{tabular}

\section{RESULTS}

The cluster analysis of leaf, flower, and inflorescence variables indicated two morphological groups, each subdivided into two subgroups that correspond to the sex of the individuals (Figure 2A). Three people who did not participate in the study classified the trunk bark images into two groups, designated as "fissured" and "scaly" types. Disagreement as to bark class occurred only for three plants among the 38 

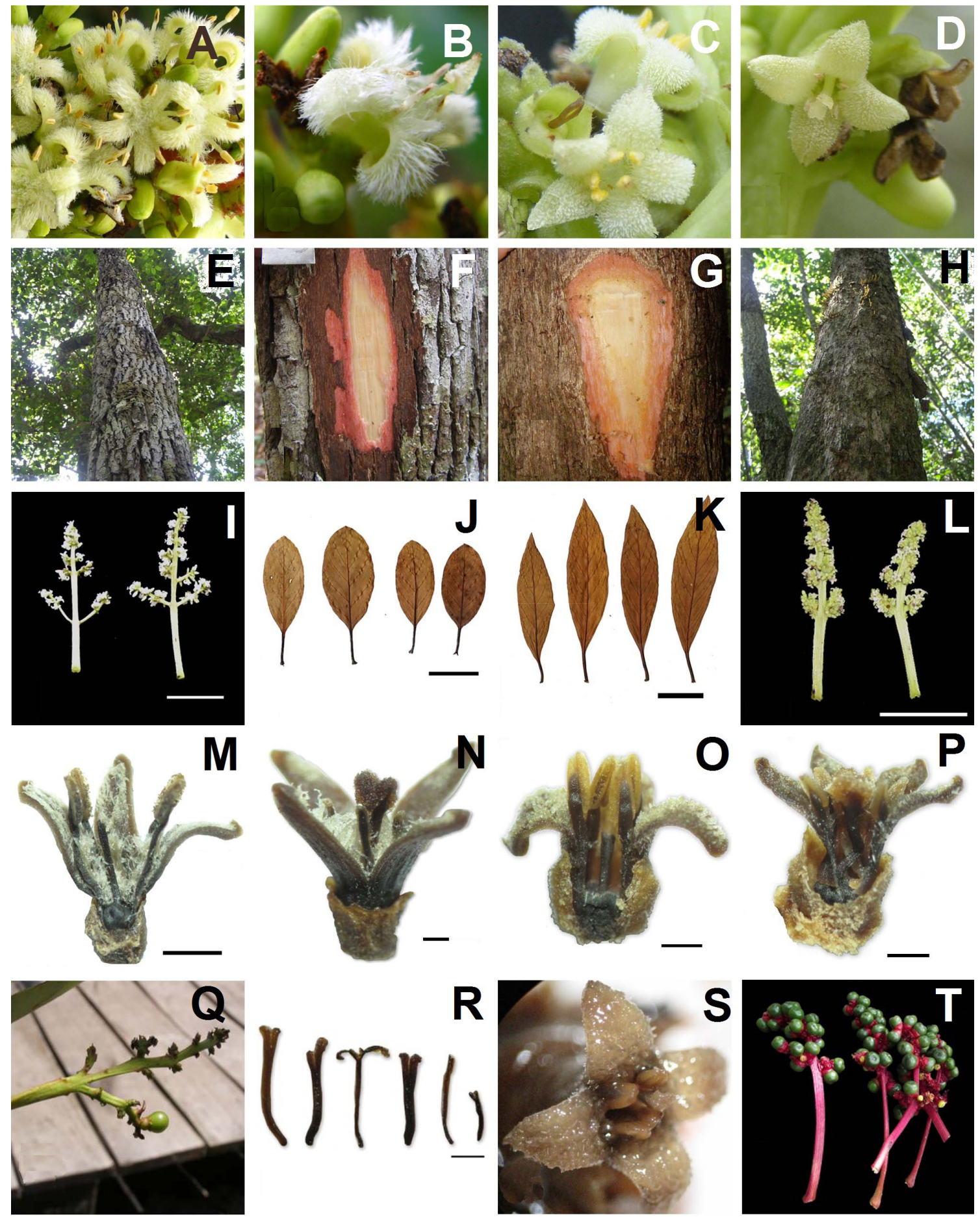

Figure 1 - Photos comparing groups A (left) and B (right). (A-D) Staminate and pistillate flowers of groups A and B, respectively. (E-H) Photos of the trunk's external and internal bark for groups $A$ and $B$. (I-L) Inflorescences and leaves of groups $A$ and $B$ (scale $=5 \mathrm{~cm}$ ). Longitudinal cuts showing the relative positions of the stamina and pistils for staminate and pistillate flowers for groups $A(M, N)$ and $B(0, P)$, (scale $=1 \mathrm{~mm})$. (Q) Inflorescence of a staminate plant of group A, with a single fruit. (S) Hermaphroditic plant of group B, showing variation in pistil size (R). (T) Infructescens of a pistillate plant of group $B$, with many fruits. 
images analyzed. The bark type classification was mapped over the cluster analysis and correlated with the two main morphological groups, designated hereafter as group A and group $\mathrm{B}$, respectively.

The ordination analysis (PCA) of leaf shape indicated that 93.6\% of the variation could be explained in two axes. The first axis (PC1) detected $88.5 \%$ of variation and discerned individuals with narrow elliptic leaves with acute apex, from individuals with broad elliptic leaves with rounded apex. The second axis (PC2) detected $5.1 \%$ of the variation, discerning mainly leaf bilateral symmetry. Leaf shape groups also corresponded to groups A and B (Figure 2B).

The multivariate analysis of variance (MANOVA) showed that the morphological differences between groups $\mathrm{A}$ and $\mathrm{B}$ were significant $\left(\mathrm{p}=3.059 \times 10^{-16}\right)$ (Table 3). The canonical discriminant analysis (CDA) indicated that variables describing leaf shape, inflorescence structure and flower size were the most important for distinguishing groups $\mathrm{A}$ and $\mathrm{B}$ (Figure 2C). The length of the first secondary axis was the most important inflorescence variable (Infl.Branch in Figure 2C; Figure 1). Both groups also differed in the ratio between peduncle length and total inflorescence length (InflShapeI in Figure 2C). Inflorescence peduncle length, petiole length and calyx length had little importance in the separation of the two groups.

Thus, morphometric analyses sustain the recognition of two morphological groups in Pagamea coriacea s.l. occurring in sympatry in the study area. Plants of group A have trunks with fissured bark, broad leaves with rounded apex, inflorescences with long basal secondary axis, and larger flowers; those of group B have scaly bark, acute and narrow elliptic leaves, inflorescences with sessile secondary axes, and smaller flowers (Figure 1).

As to the sexual system, the populations of both groups presented three sexual morphs: pistillate, staminate and hermaphroditic plants. The flowers are white and predominantly dimorphic, distinguished by the relative stigma and stamen height as staminate or pistillate (Figure 1 A-D; M-P; Figure 3 C). Although the flowers of most individuals measured fit in one of these sex categories, in the group B, two individuals presented homostylic flowers, i.e. flowers having the difference in stamen-stigma heights close to zero (Figure

Table 3 - Results of the multivariate analysis of variance (MANOVA) showing the morphological and ecological variables distinguishing the groups A and B.

\begin{tabular}{|c|c|c|c|c|}
\hline Variable & $\begin{array}{c}\text { Average } \pm \text { SD } \\
\text { Group A }\end{array}$ & $\begin{array}{c}\text { Average } \pm \text { SD } \\
\text { Group B }\end{array}$ & $\mathrm{F}$ & $P$ \\
\hline MORPHOLOGICAL & & & 51 & $<2.2 \mathrm{e}-16^{* \star *}$ \\
\hline Leaf length & $141.04 \pm 23.5$ & $176.74 \pm 31$ & 25.59 & $3.798 \mathrm{e}-06$ *** \\
\hline Leaf width & $44.36 \pm 7.1$ & $38.59 \pm 6.6$ & 11.35 & 0.001282 ** \\
\hline Petiole length & $34.47 \pm 5$ & $34.59 \pm 7.8$ & 0.0043 & 0.9481 \\
\hline Leaf Shape I & $0.42 \pm 0.1$ & $0.27 \pm 0$ & 183.44 & $<2.2 \mathrm{e}-16$ *** \\
\hline Leaf Shape II & $0.25 \pm 0$ & $0.2 \pm 0$ & 55.647 & $2.891 \mathrm{e}-10 * * *$ \\
\hline Calyx & $2.11 \pm 0.3$ & $1.99 \pm 0.3$ & 2.3729 & 0.1284 \\
\hline Stigma height & $4.11 \pm 1.2$ & $2.82 \pm 1$ & 22.435 & $1.249 \mathrm{e}-05 * \star \star$ \\
\hline Stigma length & $0.9 \pm 0.3$ & $0.71 \pm 0.3$ & 7.6193 & 0.007524 ** \\
\hline Stamen height & $4.8 \pm 0.8$ & $3.07 \pm 0.4$ & 133.08 & $<2.2 \mathrm{e}-16 * \star *$ \\
\hline Anther length & $1.3 \pm 0.3$ & $1.04 \pm 0.2$ & 20.438 & $2.723 \mathrm{e}-05 * * *$ \\
\hline Inflorescence length (IL) & $139.81 \pm 23.2$ & $111.16 \pm 24.4$ & 22.977 & $1.015 \mathrm{e}-05^{\star \star \star}$ \\
\hline Inflorescence peduncle length (PL) & $60.56 \pm 15.6$ & $57.48 \pm 14.7$ & 0.6652 & 0.4178 \\
\hline Inflorescence branch length & $41.55 \pm 11.2$ & $12.58 \pm 9.1$ & 133.91 & $<2.2 \mathrm{e}-16$ *** \\
\hline Shape I (PL/IL) & $0.43 \pm 0.1$ & $0.52 \pm 0.1$ & 24.462 & $5.781 \mathrm{e}-06$ *** \\
\hline ENVIRONMENTAL & & & 45.059 & $2.2 \mathrm{e}-16$ *** \\
\hline Root mat thickness & $6.14 \pm 5.3$ & $9.22 \pm 6.5$ & 9.9599 & 0.001916 ** \\
\hline Depth to the bedrock & $82.04 \pm 35.3$ & $29.14 \pm 33.6$ & 92.148 & $2.2 \mathrm{e}-16$ *** \\
\hline Litter thickness & $5.67 \pm 3.7$ & $4.21 \pm 2$ & 10.242 & 0.001659 ** \\
\hline Shade Index & $3.73 \pm 1$ & $5.77 \pm 2$ & 57.854 & 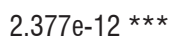 \\
\hline
\end{tabular}

** Significant p-value *** highly significant p-value. 

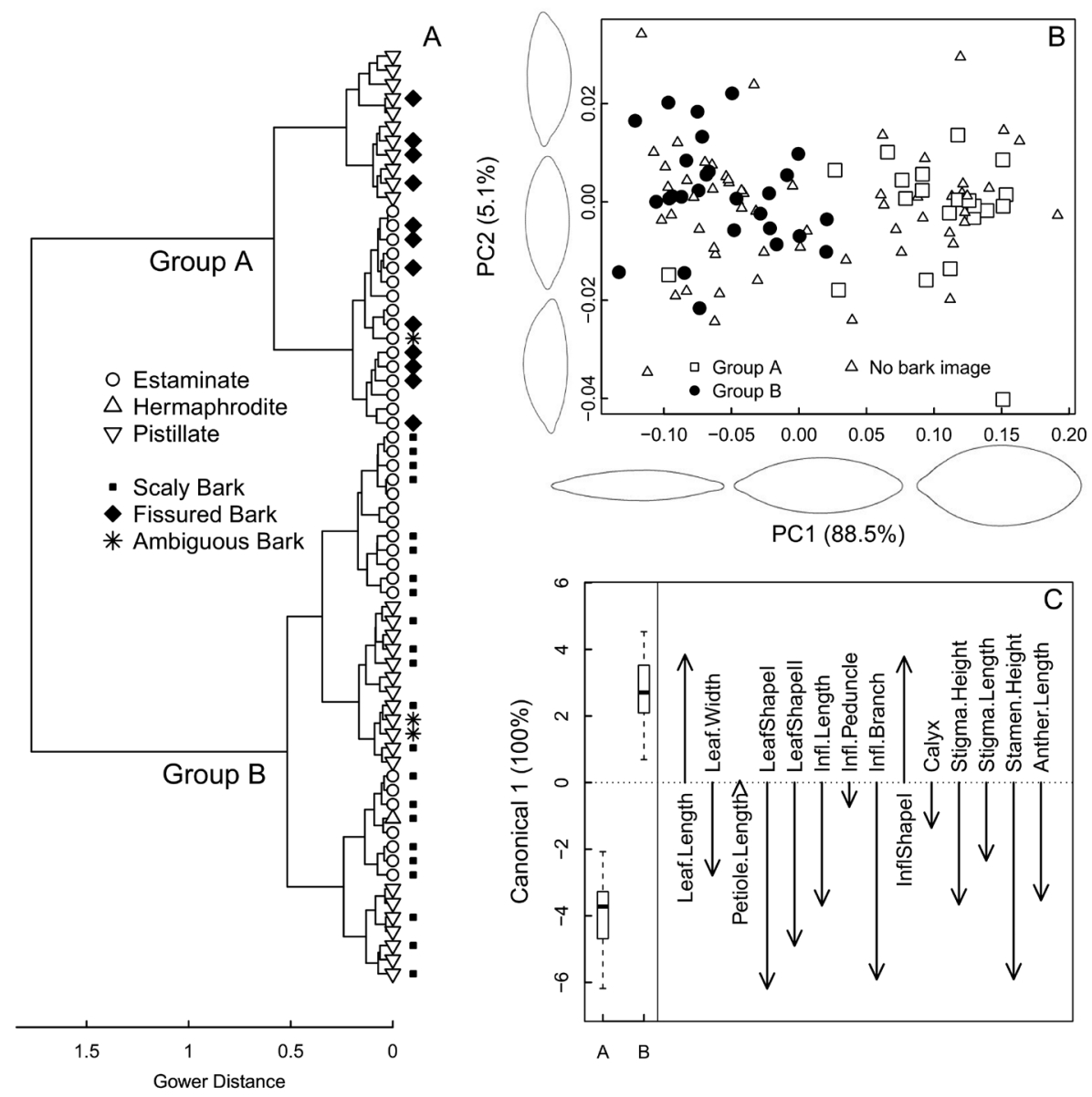

Figure 2 - (A) Cluster analysis for morphological variables of leaves, flowers, and inflorescences, produced using the Gower coefficient and the minimum variance method (Ward) ( $\mathrm{N}=67)$. Symbols indicate pistillate, staminate, and hermaphroditic flowers according to the caption. Trunk bark images were categorized into "fissured" or "scaly" and then mapped over the cluster analysis $(\mathrm{N}=38)$. Three bark images were ambiguous. (B) Ordination plot of a principal component analysis (PCA) of the normalized elliptical Fourier descriptors - NEFDs that describe leaf blade shape variation. Each dot represents the average PCA values per individual plant ( $\mathrm{N}$ leaves $=438, \mathrm{~N}$ individuals $=110$ ). (C) Results of a Canonical Discriminant Analysis, showing the canonical scores per morphological group and relative effects of each morphological variable in group discrimination (arrow lengths). See Table 3 for effects and values.

3C). One such individual had pistillate flowers with sterile stamens, but the other had clearly hermaphroditic flowers, always with fertile stamens and ample variation in pistil size, from very reduced like in staminate plants, to long and positioned at the same height as the stamens, with papillose and well-developed stigmas (Figure 1 R, S).

In the field, 306 plants were monitored for phenology, including 38 staminate and 31 pistillate plants of group A, and 56 staminate, 42 pistillate and one hermaphrodite plant of group B. We observed that pistillate plants produced a large quantity of fruits (Figure $1 \mathrm{~T}$ ), while staminate plants mostly produced only pollen. However, we observed fruit development in 13 staminate plants of group $B$, corresponding to $23 \%$ of the plants monitored. For group A, only two individuals $(5 \%)$ produced fruits. In both cases, these 'staminate' plants had always few fruits per inflorescence, and few inflorescences with fruits (Figure 1Q). Cross-sections through the ovary of staminate flowers confirmed ovule presence, as in pistillate flowers.

The flowering and fruiting periods were similar for groups $\mathrm{A}$ and B. For both, developing inflorescences were first detected in August, the first flowers in September, and the last ones in December. Fruits were first observed in October for group A and in November for group B (Figure 3A). In contrast, flower maturation in inflorescences was clearly different for both groups. For group A, nearly all buds in the inflorescences developed completely and remained closed. Afterwards, a group of flowers bloomed while the remaining buds remained closed. A period ensued when no open flowers could be found, and a new cycle initiated with the opening 

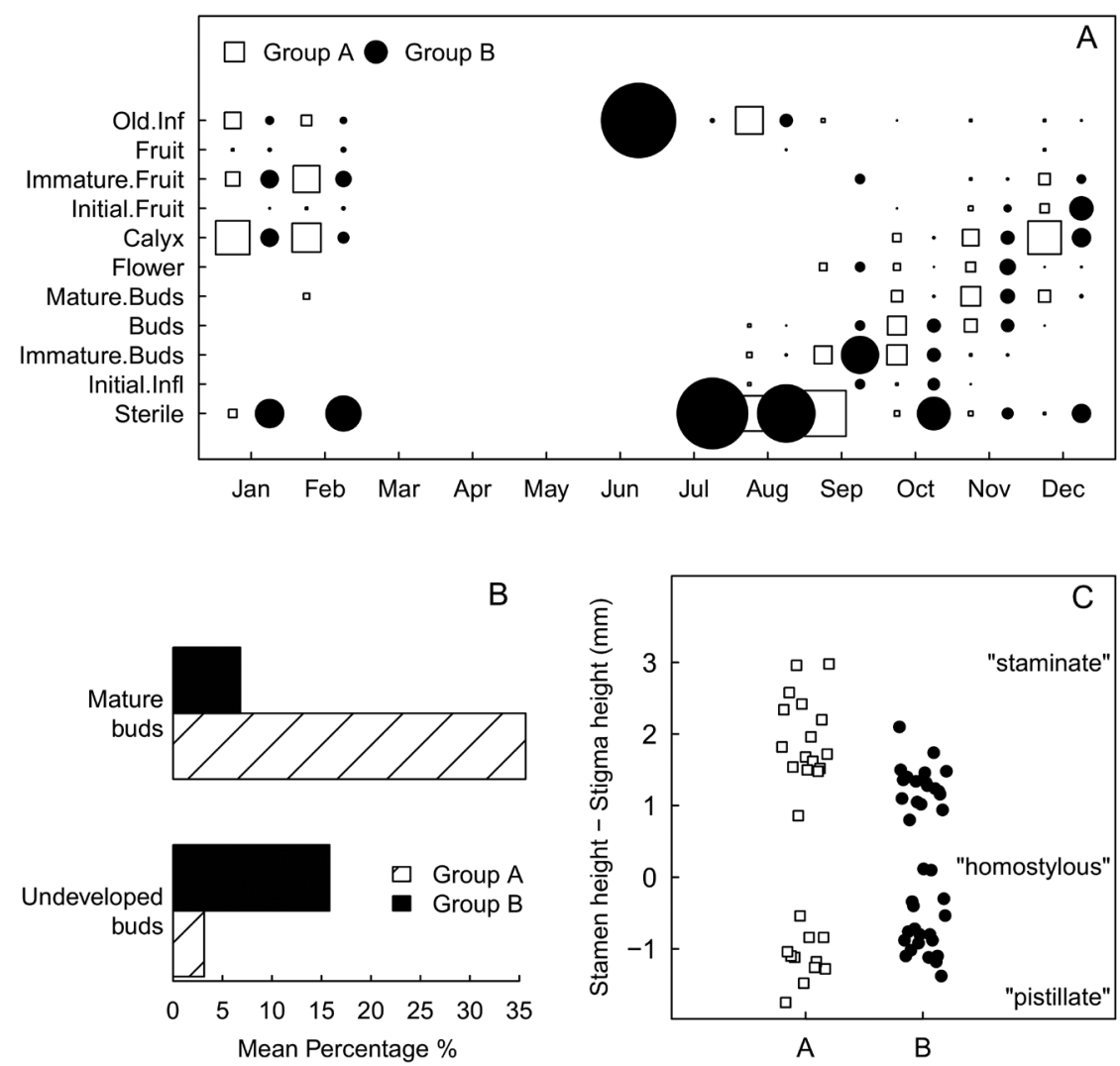

Figure 3 - Reproductive behavior of Pagamea coriacea s.I.. (A) Observations of 11 phenophases for morphological groups A and B. Phenophases are ordered in chronological sequence along the $Y$ axis from bottom to top. Monthly observations are from August 2010 to February 2011. Circle size indicates the number of observations (individuals) in each phenophase. (B) Proportions of the different stages of flower development for groups $A(n=12)$ and $B(n=11)$, showing the difference in the proportion of mature vs. immature buds between the two groups. (C) Dispersion plot, showing sexual variation as the difference between stamen height and stigma height for flower in each group.

of a new cluster of flowers, and so forth, until the end of the flowering period. On the other hand, group B showed a slow and continuous bud maturation process, with few flowers being produced every day. Insects of several orders, mainly Hymenoptera, but also Lepidoptera and Diptera, were observed visiting flowers of both groups.

The ecological variables revealed differences among the environments occupied by groups A and B in relation to root mat thickness, litter thickness, depth to the bedrock, and shade index (Figure 4). The multivariate analysis of variance (MANOVA) showed that the differences were significant $\left(\mathrm{p}=2.2 \times 10^{-16}\right.$, Table 3$)$, and the two most important variables were depth to the bedrock and the shade index. The plants of group A were found predominantly in environments where no bedrock was detected within $50 \mathrm{~cm}$ of soil depth, and 52 of 66 plants where growing in such deep soil. On the other hand, for group B, bedrock was detected for 78 of the 92 plants sampled. As to shade index, data showed that adult plants of group A occupied the canopy with the exception of a few individuals, or were found in open vegetation. On the other hand, adult plants of group B distributed homogeneously from the canopy to 4 meters below the canopy, most being in shaded situations.

The classification of the 116 individuals of $P$. coriacea s.l. measured by Vicentini (2007), according to the groups $A$ and $B$, suggested that both these groups occur along the entire distribution of the complex, and are sympatric at other sites as well (Figure 5A). The type specimens of all three varieties described by Steyermark (1965) were included among these samples: Spruce 2026 (var. coriacea) and Ducke 683 (var. pubescens) were both predicted with $99 \%$ probability as belonging to group A; while Schultes \& Cabrera 19367 (var. acuta) was predicted with $73 \%$ probability as belonging to group B. An ANOVA performed for Vicentini's (2007) data, with 85 plants of group $A$ and 10 of group B, indicated differences in shade index, and reinforced the pattern found in Presidente Figueiredo, with group A being present in more open areas (plants in the canopy), and group B in more shaded 

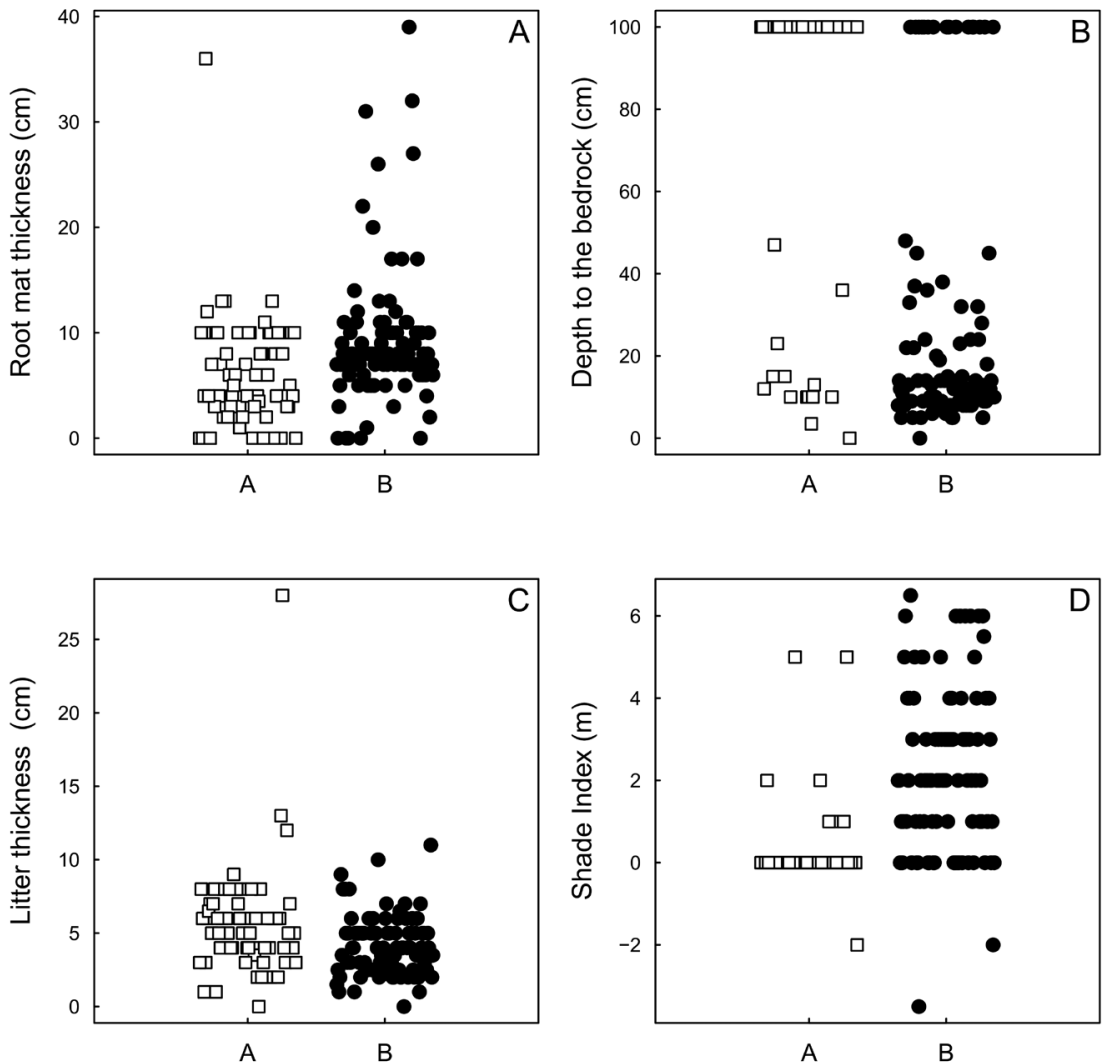

Figure 4 - Dispersion plots showing the differences between groups $A$ and $B$ in relation to four continuous variables describing the environment (N=160, $A=66$ and $B=94)$. In $(B)$, the depth to the bedrock values of $100 \mathrm{~cm}$ represent the limit measured and so "deep soils". In (D), the shade index refers to the difference between plant height and canopy height in meters.
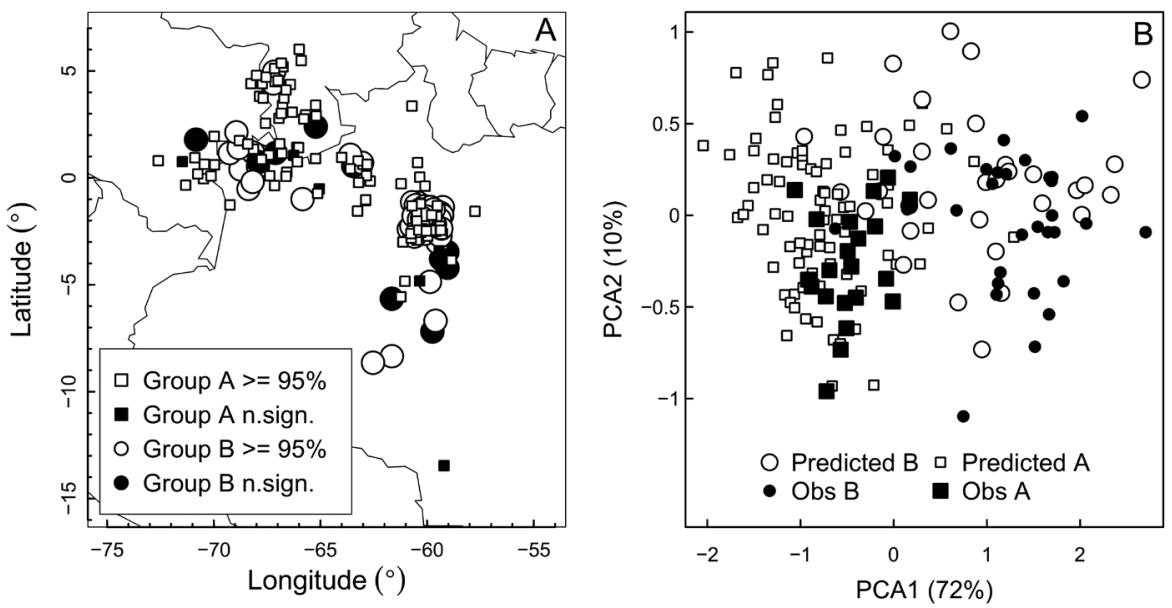

Figure 5 - Groups A and B over the entire geographical range of the Pagamea coriacea complex, according to the classification of specimens by Vicentini (2007) based on the groups defined at the local scale by the present study. (A) Geographical distribution of specimens predicted as belonging to group A and $B$, with indication of the confidence in assignment to group: empty symbols for $95 \%$ confidence, filled symbols for uncertain predictions. Samples for groups $A$ and $B$ observed in this study are included in the figure. (B) Principal component analysis (PCA) of morphological variables for the same samples as in (A), with indication of observed (this study) and predicted (Vicentini 2007) group membership. 
areas $\left(F_{1.93}=4.6339, p=0.03393\right)$. A PCA ordination of all data (Vicentini 2007 and this study) suggests, however, that these groups are not as discrete as we observed in Presidente Figueiredo (Figure 5B).

\section{DISCUSSION}

Our results support the existence of two morphologically and ecologically distinct groups of plants belonging to Pagamea coriacea s.l, which co-occur in the region of Presidente Figueiredo and possibly at other sites. These differences are found in sympatry and are indicative of species differences.

Phenotypic plasticity within a single species would be another plausible explanation for the observed patterns of variation, since there are also environmental differences among the two morphological groups, with group A occurring in more open areas, and group B in more shaded situations. However, this seems not to be the case, and these differences appear to be conserved and indicative of species differences. First, variation in morphology related to plasticity is expected for vegetative characters (Bradshaw 1965), and the two groups differed also in inflorescence structure, bark type, flower size and, more importantly, flower opening behavior. Secondly, the morphological difference between the two groups is very strong, and individuals of different sexes cluster together in the same group independently. This weakens the hypothesis of phenotypic plasticity. Thirdly, the relation between morphological variation and environment should be specific in the case of phenotypic plasticity, and we observed individuals of both groups occurring side-by-side, and maintaining the distinct morphological characteristics. Hence, it is unlikely that the morphological differences found result from phenotypic plasticity.

The ecological differences found between the two groups are similar to ecological differences among other closely related species of Pagamea (Vicentini 2007). The difference in light preference between group A and B appears to be conserved over the geographical range of the complex. Furthermore, the data from this study suggest that plants of group A prefer deeper and better-drained soils, and those of group $B$ shallower and poorly-drained soils. White-sand vegetation may be quite variable in structure and composition, mostly associated with flooding levels and altitude (Kubiztki 1990, Vicentini 2004), or with micro-variation in soil texture and fertility (Damasco et al 2013). Apparently, habitat specialization had an important role in the diversification of Pagamea, showing a trend towards niche conservatism as to inundation, and differential specialization of sister species in relation to forest structure and tolerance to light; so when species coexist in the same locality, they tend to show preference for distinct habitats in relation to flooding and shade (Vicentini 2007), as found in the present study.
The overlap in flowering time between the two sympatric morphological groups makes inter-specific crossing possible, especially if pre-zygotic barriers are not efficient (Coyne and Orr 2004; Paun et al. 2009). Although flowering time overlapped, the patterns of flower maturation differed and suggested that the groups may be associated with pollinators with distinct foraging behaviors. In the pattern observed for group B, the availability of few flowers each day throughout the entire flowering period can attract pollinators with a fixed foraging behavior, which learn the location of plants and visit them on a daily basis (Gentry 1974; Janzen 1971). On the other hand, the high availability of flowers in discontinuous moments, as observed for group A, should attract a larger number of pollinators with an opportunistic behavior (Augspurger 1980; Jong et al 1992). Nonetheless, floral morphology in Pagamea is highly conserved and suggests pollination by generalist insects (Vicentini 2007). In this study, several species of insects were observed visiting flowers of both groups indistinctly. Because there was no temporal isolation in the flowering periods of groups $\mathrm{A}$ and $\mathrm{B}$, and flower visitors were the same, we cannot rule out that plants of group A receive pollen from those of group B and vice-versa.

The sexual systems of both groups, with pistillate, staminate and hermaphroditic plants, can be characterized as a transition from dioecious to gynodioecious systems (Barrett and Case 2006). While "pistillate" plants were completely unisexual, the fruit production by "staminate" plants, and the individual with hermaphroditic and homostylous flowers, may represent a reversal in the sterility of the gynoecium, and a transition from unisexual condition to hermaphroditism. In the phylogeny of Pagamea there is a basal grade including species with homostylous and hermaphroditic flowers, and a large clade including dimorphic and functionally dioecious species, both likely derived from an heterostylous ancestral condition, with homostylous plants having dimorphism in pollen size and production; the sexual systems being inferred from the morphology of flowers (Vicentini 2007). The single study on the floral and pollination biology in Pagamea indicates that Pagamea duckei, which is sister to remaining dioecious species, is indeed functionally dioecious (TerraAraújo et al. 2012). Moreover, within the dioecious clade, only $P$. coriacea s.l. shows variation in sexual system, thus the presence of homostyly and hermaphroditism in this group appears to represent a transition from a functionally dioecious ancestral (Barret 2002). A possible cause for such reversal may be related to polyploidization events, as reported by Naiki and Nagamasu (2004) for Damnacanthus, another Rubiaceae, but cytogenetic data for Pagamea are inexistent. The variation observed within P. coriacea s.l. makes this lineage particularly interesting for studying transitions between sexual systems in plants. However, contrary to the expected, the observed 
variation did not relate to species differences, as both groups presented a similar mixed dioecious-gynodioecious system.

The coexistence of the two morphologically and ecologically distinct groups in the study area, and apparently throughout the geographical distribution of the complex, suggests that groups A and B are reproductively isolated lineages. Reproductive isolation may be only "substantial" (see Coyne and Orr 2004) because there is no temporal isolation in flowering, and the groups may share pollinators. Additional experimental and/or genetic data are necessary to test for reproductive isolation directly; but the observed differences indicate that either current gene flow is limited/absent, or it has been historically.

A taxonomic implication of the results here presented is that Pagamea coriacea var. acuta should be raised to the species level, since the type of this name was predicted as belonging to group B (but with low probability), while the type of Pagamea coriacea var. coriacea was predicted as belonging to group A. However, the limits of these two species along their entire geographical distribution remain unclear, and are being examined by an ongoing phylogeographical study. Therefore, we restrain in proposing nomenclatural changes at this stage.

The results of this study illustrate how the low knowledge of the Amazon flora stems, not only from the scarcity of collections (Hopkins 2007), but also from the lack of detailed studies in local situations and at the population level. Similar studies using morphological data in sympatric conditions also revealed cryptic diversity in Amazonian species (Gentry 1981; Costa 2004), and jointly suggest that many of the widely distributed and polymorphic "species" of the region may represent complexes that include more than one species.

\section{ACKNOWLEDGMENTS}

We thank the Conselho Nacional de Desenvolvimento Científico e Tecnológico (CNPq) for a graduate scholarship to the first author; the Schwade family for field support; Pare\&Leve for food support; Evilson Assunção da Silva and others for assistance in the field; Nallaret Dávila Cardozo, Maihyra Pombo for the classification of bark images; the Graduate Program in Botany of INPA for support; Pedro Santos for translation of early version of the manuscript, and to four anonymous reviewers whose comments greatly improved the manuscript. This study was part of the master's dissertation of the first author at the Graduate Program in Ecology at INPA, to which we are greatly indebted.

\section{REFERENCES}

Augspurger, C.K. 1980. Mass-flowering of a tropical shrub (Hybanthus prunifolius): influence on pollinator attraction and movement. Evolution, 34: 475-488.
Barrett, S.C.H. 2002. The evolution of plant sexual diversity. Nature Reviews Genetic, 3: 274-284.

Barrett, S.C.H.; Case, A. L. 2006. The ecology and evolution of gender strategies in plants: the case of Australian Wurmbea (Colchicaceae). The Turner review no. 11. Australian Journal of Botany, 54: 417-433.

Bradshaw, A.D. 1965. Evolutionary significance of phenotypic plasticity in plants, p.115-155. In: Caspary, E.M.; Thoday, J.M. (Eds.). Advances in Genetics. Academic Press, New York.

Brower, A.V.Z. 2006. Problems with DNA barcodes for species delimitation: "ten species" of Astraptes fulgerator reassessed (Lepidoptera: Hesperiidae). Systematics and Biodiversity, 4: 127-132.

Costa, M.A.S. 2004. Estudo comparativo dos morfotipos de Cordia nodosa Lam. (Boraginaceae) na Reserva Florestal Adolpho Ducke, Manaus- $A M$, baseado em análise morfológica, ecológica e molecular. Master's Dissertation, Instituto Nacional de Pesquisas da Amazônia, Manaus, Amazonas. 77p.

Coyne J.A.; Orr H.A. 2004. Speciation. Sinauer Associates, Sunderland, MA, USA. 545 pp.

Damasco, G.; Vicentini, A; Castilho, C.V.; Pimentel, T.P.; Nascimento, H.E.M. 2013. Disentangling the role of edaphic variability, flooding regime and topography of Amazonian white-sand vegetation. Journal of Vegetation Science, 24: 384-394.

De Queiroz, K. 1998. The general lineage concept of species, species criteria, and the process of speciation, p. 57-75. In: Howard, D.J.; Berlocher, S.H. (Eds.). Endless forms: species and speciation. Oxford University Press, Oxford, U.K.

De Queiroz, K. 2007. Species Concepts and Species Delimitation. Systematic Biology, 56: 879-886.

Faivre, E.A.; McDade, L.A. 2001. Population-level variation in the expression of heterostyly in three species of Rubiaceae: reciprocal placement of anthers and stigmas characterize heterostyly. American Journal of Botany, 88: 841-853.

Freeman, H. 1974. Computer processing of line drawing images. Computer Survival, 6: 57-97.

Furuta, N.; Ninomiya, S.; Takahashi, S.; Ohmori, H., Ukai, Y. 1995. Quantitative evaluation of soybean (Glycine max L., Merr.) leaflet shape by principal component scores based on elliptic Fourier descriptor. Breeding Science, 45: 315-320.

Gentry, A.H. 1974. Flowering phenology and diversity in tropical Bignoniaceae. Biotropica, 6: 54-68.

Gentry, A.H. 1981. Distributional patterns and an additional species of the Passiflora vitifolia complex: Amazonian species diversity due to edaphically differentiated communities. Plant Systematics and Evolution, 137: 95-105.

Gonzalez, M.A.; Baraloto, C.; Engel, J.; Mori, S.A.; Pétromelli, P.; Riéra, B.; Roger, A.; Thébaud, C.; Chave, J. 2009. Identification of Amazonian trees with DNA barcodes. PloS ONE, 4:1-7.

Grant, V. 1981. Plant Speciation. Columbia University Press. New York, NY, EUA. 563 pp.

Hebert, P.D.N.; Ratnasingham, S.; de Waard, J.R. 2003. Barcoding animal life: cytochrome $\mathrm{c}$ oxidase subunit 1 divergences among closely related species. Proceedings of the Royal Society of London. Series B: Biological Sciences, 270: 596-599. 
Hickerson, M.J.; Meyer, C.; Moritz C. 2006. DNA barcoding will fail to discover new animal species over broad parameter space. Systematic Biology, 55: 729-739.

Hopkins, M.J.G. 2007. Modeling the known and unknown plant biodiversity of the Amazon Basin. Journal of Biogeography, 34: 1400-1411.

Iwata, H.; Ukai, Y. 2002. SHAPE: A computer program package for quantitative evaluation of biological shapes based on elliptic Fourier descriptors. Journal of Heredity, 93: 384-385

Janzen, D.H. 1971. Euglossine bees as long-distance pollinators of tropical plants. Science, 171: 203-205.

Jong, T.J.; Klinkhamer, P.G.L.; Van Staalduinen, M. J. 1992. The Consequences of Pollination Biology for Selection of Mass or Extended Flowering. Functional Ecology, 6: 606-615.

Knowles, L.L.; Carstens, B.C. 2007. Estimating a geographically explicit model of population divergence for statistical phylogeography. Evolution 61: 477-493.

Kubitzki, K. 1990. The Psammophilous Flora of Northern South America. Memoirs of the New York Botanical Garden, 64:248-253.

Leaché, A.D.; Koo, M.S.; Spencer, C.L.; Papenfuss, T.J.; Fisher, R.N.; McGuire, J. A. 2009. Quantifying ecological, morphological, and genetic variation to delimit species in the coast horned lizard species complex (Phrynosoma). Proceedings of the National Academy of Sciences, 106: 12418-12423.

Marshall, J.C.; Arévalo, E.; Benavides, J.; Sites, J.W.Jr. 2006. Delimiting species: Comparing methods for Mendelian characters using lizards of the Sceloporus grammicus (Squamata: Phrynosomatidae) complex. Evolution, 60: 1050-1065.

Mitchell-Olds, T.; Schmitt, J. 2006. Genetic mechanisms and evolutionary significance of natural variation in Arabidopsis. Nature, 441: 947-952.

Mayden, R.L. 1997. A hierarchy of species concepts: The denouement in the saga of the species problem, p. 381-424. In: Claridge, M. F.; Dawah, H. A.; Wilson, M. R. (Eds.). Species: the units of biodiversity. Chapman and Hall, London, UK.

Mayr, E. 1992. A local flora and the biological species concept. American Journal of Botany, 79: 222-238.

McDade, L.A. 1995. Species concepts and problems in practice: Insight from Botanical Monographs. Systematic Botany, 20: 606-622

Morando, M.; Avila, L.J.; Sites, J.W.Jr. 2003. Sampling strategies for delimiting species: Genes, individuals, and populations in the Liolaemus elongatus-kriegi complex (Squamata: Liolaemidae) in Andean-Patagonian South America. Systematic Biology, 52: 159-185.

Naiki, A.; Nagamasu, H. 2004. Correlation between distyly and ploidy level in Damnacanthus (Rubiaceae). American Journal of Botany, 91: 664-671.

Paun, O.; Forest, F.; Fay, M.F.; Chase, M.W. 2009. Hybrid speciation in angiosperms: parental divergence drives ploidy. New Phytologist, 182: 507-518.

Pons, J.; Barraclough, T.G.; Gomez-Zurita, J.; Cardoso, A.; Duran, D.P.; Hazell, S.; Kamoun, S.; Sumlin, W.D.; Vogler, A.P. 2006.
Sequence-based species delimitation for the DNA taxonomy of undescribed insects. Systematic Biology, 55:595-609.

Prance, G.T. 1996. Islands in Amazonia. Philosophical Transactions of the Royal Society, 351: 823-833.

R Core Team. 2012. R: A language and environment for statistical computing. R Foundation for Statistical Computing, Vienna, Austria. ISBN 3-900051-07-0. (http://www.R-project.org/). Accessed on 29/05/2012.

Rasband, W. 2004. Image J. National Institute of Health, USA. (http://imagej.nih.gov/ij) Accessed on 15/01/2011.

Reeves, P.A.; Richards, C.M. 2011. Species Delimitation under the General Lineage Concept: An Empirical Example Using Wild North American Hops (Cannabaceae: Humulus lupulus). Systematic Biology, 60: 45-59.

Schlichting, C. 1986. The evolution of phenotypic plasticity in plants. Annual Review of Ecology and Systematics, 17: 667-93.

Shaffer, H.B.; Thomson, R.C. 2007. Delimiting Species in Recent Radiations. Systematic Biology, 56: 896-906.

Sites, J.W.Jr.; Marshall, J.C. 2004. Operational criteria for delimiting species. Annual Review of Ecology Evolution and Systematics, 35: 199-227.

Steyermark, J. A. 1965. Botany of the Guayana highlands - part VI - Rubiaceae. Memoirs of the New York Botanical Garden, 12: 263.

Templeton, A.R. 2001. Using phylogeographic analyses of gene trees to test species status and processes. Molecular Ecology, 10: 779-791.

Terra-Araújo, M.H.; Webber, A.C.; Vicentini, A. 2012. Pollination of Pagamea duckei Standl. (Rubiaceae): a functionally dioecy species. Biota Neotropica. 12: 98-104.

Valcárcel, V.; Vargas, P. 2010.Quantitative morphology and species delimitation under The General Lineage Concept: optimization for Hedera (Araliaceae). American Journal of Botany, 97: 1555-1573.

Veloso, H.P.; Rangel Filho, A.L.R.; Lima, J.C.A. 1991. Classificação da vegetação brasileira adaptada a um sistema universal. Instituto Brasileiro de Geografia e Estatística, Rio de Janeiro. 144 pp.

Vicentini, A. 2007. Pagamea Aubl. (Rubiaceae), from species to processes, building the bridge. Doctoral Thesis, University of Missouri Saint Louis. 330 pp. (https://apps.umsl.edu/webapps/ weboffice/ETD/search.cfm). Accessed on 10/08/2010.

Wiens, J.J. 2007. Species delimitation: New approaches for discovering diversity. Systematic Biology, 56: 875 - 878.

Will, K.W.; Mishler, B.D.; Wheeler, Q.D. 2005. The perils of DNA barcoding and the need for integrative taxonomy. Systematic Biology, 54: 844-851.

Zappi, D. 2012. Pagamea in Lista de Espécies da Flora do Brasil. Jardim Botânico do Rio de Janeiro (http://floradobrasil.jbrj.gov. br/2012/FB020786). Accessed on 10/10/2012.

Recebido em: 02/06/2012

Aceito em: 10/11/2012 
Appendix I - List of fertile vouchers for trees of Pagamea coriacea s.I. monitored for this study from three different localities in Presidente Figueiredo, Amazonas Brazil. All these specimens were deposited in the INPA herbarium.

\begin{tabular}{|c|c|c|c|c|c|c|}
\hline Collector & Num & Group & Date & Locality & Latitude & Longitude \\
\hline Esteves, S.M. & 58 & $\mathrm{~B}$ & $2010-11-07$ & Iracema & -1.9908774365 & -60.0569427386 \\
\hline Esteves, S.M. & 59 & $A$ & $2010-12-01$ & Iracema & -1.9909268059 & -60.0569730811 \\
\hline Esteves, S.M. & 72 & B & 2010-11-06 & Iracema & -1.9908774365 & -60.0569427386 \\
\hline Esteves, S.M. & 73 & B & $2010-11-23$ & Iracema & -1.9926563278 & -60.0565469451 \\
\hline Esteves, S.M. & 75 & A & 2010-11-07 & Princesinha do Urubu & -2.0492127165 & -60.124961799 \\
\hline Esteves, S.M. & 76 & B & $2010-11-07$ & Princesinha do Urubu & -2.0492127165 & -60.124961799 \\
\hline Esteves, S.M. & 77 & B & $2010-11-07$ & Princesinha do Urubu & -2.0492127165 & -60.124961799 \\
\hline Esteves, S.M. & 78 & B & $2010-11-07$ & Princesinha do Urubu & -2.0492127165 & -60.124961799 \\
\hline Esteves, S.M. & 79 & A & $2010-11-07$ & Princesinha do Urubu & -2.0492127165 & -60.124961799 \\
\hline Esteves, S.M. & 80 & B & $2010-11-07$ & Princesinha do Urubu & -2.048072191 & -60.1255044434 \\
\hline Esteves, S.M. & 82 & B & $2010-11-07$ & Princesinha do Urubu & -2.0481037069 & -60.1254915353 \\
\hline Esteves, S.M. & 83 & B & $2010-11-07$ & Princesinha do Urubu & -2.0478031319 & -60.125555573 \\
\hline Esteves, S.M. & 90 & B & $2010-11-11$ & Iracema & -1.9893218391 & -60.0580765586 \\
\hline Esteves, S.M. & 91 & A & $2010-11-11$ & Iracema & -1.9906468503 & -60.0565207936 \\
\hline Esteves, S.M. & 92 & B & $2010-11-11$ & Iracema & -1.9892100245 & -60.0580212381 \\
\hline Esteves, S.M. & 93 & B & $2010-11-11$ & Iracema & -1.9892090186 & -60.0581703521 \\
\hline Esteves, S.M. & 94 & B & $2010-11-11$ & Iracema & -1.9891490042 & -60.058018472 \\
\hline Esteves, S.M. & 95 & B & $2010-11-11$ & Iracema & -1.9887737464 & -60.0579239242 \\
\hline Esteves, S.M. & 96 & B & $2010-11-11$ & Iracema & -1.9892759901 & -60.0580176339 \\
\hline Esteves, S.M. & 97 & B & $2010-11-11$ & Iracema & -1.9890641794 & -60.0579409394 \\
\hline Esteves, S.M. & 106 & $A$ & $2010-11-12$ & $\begin{array}{l}\text { Parque Municipal } \\
\text { Orquídeas }\end{array}$ & -2.035146039 & -60.0014935154 \\
\hline Esteves, S.M. & 107 & B & $2010-11-15$ & Princesinha do Urubu & -2.0490657818 & -60.124199884 \\
\hline Esteves, S.M. & 109 & B & $2010-11-11$ & Princesinha do Urubu & -2.04930651 & -60.1241203398 \\
\hline Esteves, S.M. & 110 & B & $2010-11-15$ & Princesinha do Urubu & -2.04930651 & -60.1241203398 \\
\hline Esteves, S.M. & 111 & B & $2010-11-15$ & Princesinha do Urubu & -2.0494292211 & -60.1241871435 \\
\hline Esteves, S.M. & 112 & B & $2010-11-15$ & Princesinha do Urubu & -2.0493713859 & -60.1242033206 \\
\hline Esteves, S.M. & 113 & B & $2010-11-15$ & Princesinha do Urubu & -2.049463084 & -60.1242267061 \\
\hline Esteves, S.M. & 114 & B & $2010-11-15$ & Princesinha do Urubu & -2.0492059272 & -60.1242564619 \\
\hline Esteves, S.M. & 115 & B & $2010-11-15$ & Princesinha do Urubu & -2.0492059272 & -60.1242564619 \\
\hline Esteves, S.M. & 116 & B & $2010-11-15$ & Princesinha do Urubu & -2.0492240321 & -60.1241905801 \\
\hline Esteves, S.M. & 117 & B & $2010-11-15$ & Princesinha do Urubu & -2.0492240321 & -60.1241905801 \\
\hline Esteves, S.M. & 118 & B & $2010-11-16$ & Princesinha do Urubu & -2.0481498912 & -60.1276645437 \\
\hline Esteves, S.M. & 119 & $B$ & $2010-11-16$ & Princesinha do Urubu & -2.048446862 & -60.1276112348 \\
\hline Esteves, S.M. & 120 & B & $2010-11-17$ & Princesinha do Urubu & -2.0484447666 & -60.1277044415 \\
\hline Esteves, S.M. & 121 & B & $2010-11-17$ & Princesinha do Urubu & -2.0485803857 & -60.1275569201 \\
\hline Esteves, S.M. & 123 & B & $2010-11-17$ & Princesinha do Urubu & -2.0483280905 & -60.1276784576 \\
\hline Esteves, S.M. & 124 & B & $2010-11-17$ & Princesinha do Urubu & -2.0484759472 & -60.1276083011 \\
\hline Esteves, S.M. & 125 & B & $2010-11-17$ & Princesinha do Urubu & -2.0476240106 & -60.1275703311 \\
\hline Esteves, S.M. & 126 & B & $2010-11-17$ & Princesinha do Urubu & -2.0484347921 & -60.127581479 \\
\hline Esteves, S.M. & 128 & B & $2010-11-17$ & Princesinha do Urubu & -2.0484760311 & -60.1276128273 \\
\hline Esteves, S.M. & 129 & B & $2010-11-18$ & Iracema & -1.9905341975 & -60.0557859521 \\
\hline Esteves, S.M. & 130 & B & $2010-11-18$ & Iracema & -1.9906491973 & -60.0559845194 \\
\hline Esteves, S.M. & 131 & B & $2010-11-18$ & Iracema & -1.9905349519 & -60.0558027159 \\
\hline Esteves, S.M. & 132 & B & $2010-11-18$ & Iracema & -1.9905281626 & -60.0557556096 \\
\hline Esteves, S.M. & 133 & B & $2010-11-18$ & Iracema & -1.9905829802 & -60.0559844356 \\
\hline Esteves, S.M. & 135 & B & $2010-11-18$ & Iracema & -1.990634948 & -60.0562740304 \\
\hline Esteves, S.M. & 136 & B & $2010-11-18$ & Iracema & -1.9905989058 & -60.056236228 \\
\hline Esteves, S.M. & 137 & B & $2010-11-18$ & Iracema & -1.9906944595 & -60.056427503 \\
\hline Esteves, S.M. & 138 & $\mathrm{~B}$ & 2010-11-18 & Iracema & -1.9906468503 & -60.0565207936 \\
\hline
\end{tabular}


Appendix I - Continuation

\begin{tabular}{|c|c|c|c|c|c|c|}
\hline Collector & Num & Group & Date & Locality & Latitude & Longitude \\
\hline Esteves, S.M. & 139 & B & $2010-11-18$ & Iracema & -1.9908774365 & -60.0569427386 \\
\hline Esteves, S.M. & 140 & B & $2010-11-18$ & Iracema & -1.9906491973 & -60.0559845194 \\
\hline Esteves, S.M. & 141 & A & $2010-11-19$ & Iracema & -1.9906468503 & -60.0565207936 \\
\hline Esteves, S.M. & 142 & A & $2010-11-19$ & Iracema & -1.9904388953 & -60.0552967843 \\
\hline Esteves, S.M. & 143 & A & 2010-11-19 & Iracema & -1.9905046094 & -60.0556408614 \\
\hline Esteves, S.M. & 144 & B & $2010-11-19$ & Iracema & -1.9905061182 & -60.055625774 \\
\hline Esteves, S.M. & 145 & B & 2010-11-19 & Iracema & -1.9905111473 & -60.0556088425 \\
\hline Esteves, S.M. & 146 & B & $2010-11-19$ & Iracema & -1.9905047771 & -60.0556212477 \\
\hline Esteves, S.M. & 147 & B & $2010-11-19$ & Iracema & -1.9904025178 & -60.0556710362 \\
\hline Esteves, S.M. & 148 & B & $2010-11-19$ & Iracema & -1.9904195331 & -60.0556794181 \\
\hline Esteves, S.M. & 149 & B & 2010-11-19 & Iracema & -1.9905231334 & -60.0556105189 \\
\hline Esteves, S.M. & 150 & B & $2010-11-19$ & Iracema & -1.9904336147 & -60.0556145422 \\
\hline Esteves, S.M. & 151 & A & $2010-11-19$ & Iracema & -1.9905149192 & -60.0555998739 \\
\hline Esteves, S.M. & 152 & B & $2010-11-22$ & Princesinha do Urubu & -2.0488476008 & -60.1242242754 \\
\hline Esteves, S.M. & 153 & B & $2010-11-22$ & Princesinha do Urubu & -2.0488476008 & -60.1242242754 \\
\hline Esteves, S.M. & 154 & B & $2010-11-22$ & Princesinha do Urubu & -2.0487313438 & -60.1242061704 \\
\hline Esteves, S.M. & 155 & B & $2010-11-22$ & Princesinha do Urubu & -2.0484588481 & -60.1242669392 \\
\hline Esteves, S.M. & 158 & B & $2010-11-23$ & Iracema & -1.9926430844 & -60.0566041097 \\
\hline Esteves, S.M. & 159 & B & $2010-11-23$ & Iracema & -1.9924929645 & -60.0563453604 \\
\hline Esteves, S.M. & 160 & A & $2010-11-19$ & Iracema & -1.9906468503 & -60.0565207936 \\
\hline Esteves, S.M. & 161 & B & $2010-11-22$ & Princesinha do Urubu & -2.0474386867 & -60.1275181118 \\
\hline Esteves, S.M. & 162 & B & $2010-11-22$ & Princesinha do Urubu & -2.0487313438 & -60.1242061704 \\
\hline Esteves, S.M. & 163 & B & $2010-11-22$ & Princesinha do Urubu & -2.048656242 & -60.1241314877 \\
\hline Esteves, S.M. & 164 & B & $2010-11-22$ & Princesinha do Urubu & -2.0487313438 & -60.1242061704 \\
\hline Esteves, S.M. & 165 & B & $2010-11-22$ & Princesinha do Urubu & -2.0476240106 & -60.1275703311 \\
\hline Esteves, S.M. & 167 & B & $2010-11-22$ & Princesinha do Urubu & -2.0474386867 & -60.1275181118 \\
\hline Esteves, S.M. & 170 & B & $2010-11-22$ & Princesinha do Urubu & -2.0475393534 & -60.127545353 \\
\hline Esteves, S.M. & 171 & B & $2010-11-22$ & Princesinha do Urubu & -2.0476207417 & -60.1275691576 \\
\hline Esteves, S.M. & 172 & B & $2010-11-22$ & Princesinha do Urubu & -2.0476093423 & -60.127561111 \\
\hline Esteves, S.M. & 173 & B & $2010-11-22$ & Princesinha do Urubu & -2.0475213323 & -60.1275602728 \\
\hline Esteves, S.M. & 188 & B & $2010-11-26$ & Iracema & -1.9890055899 & -60.0574263744 \\
\hline Esteves, S.M. & 189 & B & $2010-11-26$ & Iracema & -1.988898553 & -60.057378849 \\
\hline Esteves, S.M. & 191 & B & $2010-11-26$ & Iracema & -1.9886139873 & -60.0565929618 \\
\hline Esteves, S.M. & 193 & B & $2010-11-26$ & Iracema & -1.9888857286 & -60.0567796268 \\
\hline Esteves, S.M. & 195 & & $2010-11-26$ & Iracema & -1.9895298779 & -60.0580359064 \\
\hline Esteves, S.M. & 207 & B & $2010-12-10$ & Iracema & -1.9895298779 & -60.0580359064 \\
\hline Esteves, S.M. & 208 & B & $2010-11-11$ & Iracema & -1.9889672007 & -60.0579246785 \\
\hline
\end{tabular}

